\title{
Steps for Preparation of Reading Materials Product "Kumpulan Cerpen Emansipasi Wanita" (Collection of Women's Emancipation Short Stories) in Sara's Perspective and Its Implementation as Reading Material on $10^{\text {th }}$ Grade Students of MAN Insan Cendikia, East Aceh, Indonesia
}

\author{
Intan Novita ${ }^{1}$, Biner Ambarita ${ }^{2}$, Malan Lubis ${ }^{2}$ \\ ${ }^{1}$ Master Student in State University of Medan (Unimed), Medan, Indonesia \\ ${ }^{2}$ Lecturer in State University of Medan (Unimed), Medan, Indonesia \\ intannovita323@ymail.com
}

\begin{abstract}
Reading material is one of the tasks that the teacher must do. Reading material that has an attraction for students will motivate students to read the text seriously, which in turn will support the students' reading comprehension. Reading is the most interesting thing among students, moreover reading material is very much needed for students and can add references in the school library. MAN Insan Cendikia, East Aceh does not yet have literary material. Reading material in MAN Insan Cendikia, East Aceh school is only in the form of reading about science not in the form of literature. The material expert validation stage obtained results from these assessments indicating that the feasibility aspects of the material content of reading material products were declared $86.71 \%$ with the category "Excellent". The contents are declared feasible because they are in the average value above $75 \%$ with the category "Good".
\end{abstract}

Keywords : reading materials; short stories; women's emancipation

\section{Introduction}

Nowadays, short stories are material or teaching material for schools that have implemented the 2013 curriculum. The contents of the teacher's books are several short stories, namely "Lentera Kelam Tiga Puluh Februari", "Arin dan Mimpinya", "Aini dan Burung Kecil", " Pahlawan Kecilku", "Ke Rumah Presiden", "Surat Kepada Tuhan", and "Menanam Seribu Pohon". One of the synopsis was "Lentera Kelam Tiga Puluh Februari (LMCR)". Where this short story only tells a child to find a wallet and he feels nervous about returning it or not. This story is usually wrapped up with stories and grooves that make it look like life. Hasan, the main character in this short story, he finds a wallet after school. He experiencs inner struggle and chose to save the wallet. At home, his sister finds out about the wallet. This short story conflict began. Hasan is really confused, he wants to return, but the economic situation made him have to think again. Moreover, the grandfather who has been living it by pedaling a pedicab, so craving batik cloth in his old age. The next morning, it fells different to Hasan. He himself hovere with a blue sky. He is stunned when he see the numbers exposed in his view, February 30. Hasan understood, this is the answer to his inner conflict. He finds the answer, when he really wake up, Hasan rushs to the house of the wallet owner whose findings are none other than his teacher, Pak Warto. However, the yellow flag is displayed, with regret, Hasan hands over his wallet to a crying child, Pak Warto's son. The short story is quoted in the teacher's book. From the "Lentera Kelam Tiga Puluh Februari" short story does not raise or not themed the theme "Emansipasi Wanita" (Women's Emancipation). In addition to being a teaching material, short stories can also be implemented as students' daily needs, namely short stories as reading material for students at school. From the teaching materials, the teacher can pour short stories into student reading 
material. The material can be in the form of a short story definition and collection of short stories that suit the needs of their students.

Choosing reading material is one of the tasks that the teacher must do. Reading material that has an attraction for students will motivate students to read the text seriously, which in turn will support the students' reading comprehension. Reading is the most interesting thing among students, moreover reading material is very much needed for students and can add references in the school library. One of the highlights for students about the reading title is the short story. Short stories are still one of the titles favored by any student.

Short stories with the theme "Emancipation of Women" have meaning for everyday life. The mandate that he poured was very religious so that it could be a lesson for readers. If reviewing KD 3.8 Identify the values of life contained in a collection of short stories that are read and 3.9 Analyze the elements of short story builders in a collection of short stories. Short story "Emansipasi Wanita" which is suitable to be used as reading material for $10^{\text {th }}$ Grade Students of MAN Insan Cendikia. The values which is presented by the author can be a benchmark or motivation for students, especially women who become readers. $10^{\text {th }}$ Grade students will move on to the maturity phase, so it takes a lot of good life values to be used as a benchmark and motivation for them.

\subsection{Critical Discourse Analysis}

\section{Review of Literature}

Critical discourse analysis is a decomposition of the process to give an explanation of a text (social relativity). As expressed by Barker and Galasinski (in Darma, 2009: 50) that is critical of the theory of social theory and critical linguistic analysis. Critical discourse analysis, discourse is not only but also a context. The context in this case is used for certain purposes in the world of literature.

Brown and Yule (1996: 1) suggest discourse analysis is an attempt to express the hidden intentions of the subject who puts forward a statement. This in the discourse analyzer is obliged to investigate for what language. In line with the opinion of Brown and Yule, Eriyanto (2009: 4) suggests that discourse is a study of language use. So, it can be concluded that discourse analysis is a language usage to express a statement.

In contrast to discourse analysis, critical discourse analysis is not just a language study. Finally, discourse uses language to be analyzed, but the language analyzed here is different from the study of the sense of traditional linguistics. Eriyanto, (2009: 7) language is analyzed not only describing linguistic aspects, but also connecting with context. The context of question is that the language is used for practice, including the practice of power.

\subsection{Emancipation of Women}

Mulia (2006:37) emancipation comes from English "emancipation" which means independence. Independence here is interpreted as releasing ourselves from power to further have freedom in acting, determining attitudes or not in others. The terms emancipation (English), emancipation (French), emanzipation (German), emansipatie (Dutch) and Indonesian vocabulary as emancipation. Broadly, emancipation means free from a bond, bondage, slavery, mastery and various other constraints. Whereas in the case of narrowmindedness in the law with the rights that exist in the law.

As in Kamus Besar Bahasa Indonesia (KBBI), emancipation means liberation from slavery, equality of rights from various aspects of people's lives (such as equal rights of 
women and men). Whereas women's emancipation is a process of detachment from a woman's low socio-economic position or legal restraint which limits the possibility of developing and advancing.

Ma'ani (2013: 20) The emulation is used to obtain rights and equality, often for groups that are not specifically given rights, or more generally in discussing problems.

Women come from the basic word "empu". According to Kamus Besar Bahasa Indonesia (KBBI) which means "master" and a very expert person. Whereas according to the term woman is someone who is respected and is loving. Sharma (2002: 15) in essence, women who have become wives' main task is to serve their husbands, take care of their household, become teachers for their children so that they become dedicated and useful children for their families, communities, the nation and the nation. So, we often hear the term "behind great men there are great women too".

\subsection{Sara Mills's Perspective}

Mills's view (1994: 15), discourse analysis is a reaction to formal forms of traditional linguistics. The focus of the study of traditional linguistics is on the selection of sentence structures that do not pay attention to language analysis in their use. Whereas in discourse analysis, matters relating the sentence structure and grammar are even more concerned.

Referring to Foucault's opinion, the notion of discourse is divided into several levels or levels, namely discourse seen from the theoretical conceptual level, context of use and method of explanation. In theoretical conceptual, discourse is defined as the general domain of all statements. This means that all texts have meaning and have effects in the real world. While in the context of its use, discourse means a set of statements that can be grouped into certain conceptual categories in order to identify certain structures in discourse, such as imperialism and feminism. While the notion of discourse when viewed from the method of explanation is discourse is a practice that is set to explain a number of statements.

Sara Mills has written extensively on discourse theory. However, the main focus is on discourse on feminists. The feminist perspective approach of Sara Mills focuses more on the discourse about women. How women are displayed in text, novels, pictures, photos or news. This discourse approach is often referred to as the Sara Mills perspective. The focus of the perspective of feminist discourse is to show how the text can display women. Women tend to be displayed in the text as the wrong party, marginal compared to men.

The idea of Sara Mills is somewhat different from the critical linguistics model. If critical linguistics focuses on linguistic structures and how they affect the meaning of audiences, Sara Mills looks more at how actor positions are displayed in the text. This position is in the sense of who is the subject of the image and who is the object of imaging. In addition, Sara Mills also focuses on how and the author is displayed in the text. How readers identify and place themselves in storytelling.

\subsection{Sara Mills's Concept of Critical Discourse Analysis}

The analytical concept proposed by Sara Mills is better known as a feminist perspective because she examines how women are displayed in the text, both in short stories, images, photographs and media. Women tend to be shown as wrong and marginal parties compared to men. This injustice and depiction of women is the main target in Mills's writing.

Mills (2002: 67-71) discourse analysis of feminist perspectives is influenced by Foucault's thinking about power relations. Foucault himself has never studied discourse related to women. In his ideas he did not even mention anything about women. Nevertheless, 
Mills states that Foucault's thinking is very relevant to review discourse from a feminist point of view. The concept of power relations put forward by Foucault is closely related to the feminist view. The view of feminism seeks to fight a form of patriarchal power.

Barker and Galasnski (in the journal Madasari 2007: 14) Lois McNay states in Foucault And Feminism, as cited in the book Cultural Studies and Discourse Analysis: A Dialogue on Language and Identity that: Foucault of women's oppression that seeks to avoid powerless women as victims of patriarchal structures of domination

\section{Research Methodology}

This research was a descriptive qualitative study that examines the perspective of sara mills in a collection of short stories entitled "Emansipasi Wanita". As stated by Bodgan and Taylor in Moleong (2014: 4) that qualitative methodology is a research procedure that produces descriptive data in the form of written or oral words from people and behaviors that can be desired.

Ratna (2008: 53) argues that the method of this research is a qualitative method of descriptive analysis. Descriptive analysis method is carried out by describing facts which are then followed by analysis (Ratna, 2008: 53).

The primary data source in this study is a collection of short stories "Emansipasi Wanita", while secondary data sources are related research journals and scientific articles. In addition, to obtain more robust data, information was also collected from two Indonesian language teachers at $10^{\text {th }}$ Grade Students of MAN Insan Cendikia, East Aceh.

\section{Discussion}

The result of analyzing the collection of short stories "Emansipasi Wanita" with the Sara Mills perspective is that there are two parts: the position of the subject-object and the position of the reader-writer. Sara Mills focuses on the discourse on feminism. How it is displayed in the text, both in novels, pictures, photos or in the news. The focus of perspectives on feminist discourse is to show how the text is biased in showing women. Data analysis as follows:

\subsection{Subject Position} Short Story 1

The subject in the short story "Me, Ratih, and Kartini" is Me. A teacher who is explaining a lesson for his students in class. "I" is described as a teacher who tells his story when he becomes a teacher who is listening to the story of one of his students. This is evidenced by the conversation:

"Of course, are there things you want to correct?", I tried to be democratic. For me having critical and vocal students was a dream for the advancement of this nation's education. How I like the times when I have to discuss and compete with my students.

\section{Short Story 2}

The position of the subject is described in the short story that the position is the actor or storyteller who has control to tell from the point of view experienced by him. Like the quote below: 
"As if fresh again turned to a dozen years ago, when the longest ruler in this country fell. We have both been thrown into a police truck because they were considered

\section{Short Story 3} rejecting and saying no to power ..."

The position of the subject, described in the short story that the position is the actor or storyteller who has control to tell from the point of view experienced by him such as quote:

"I was one of those who queued up 12 years ago. I held a brown envelope, my head looked up for protection. All I got was the blazing sun and the shadow of their forcing faces became clearer. ,."

\section{Short Story 4}

The position of the subject in the short story of the 20th Century Kartini is that I am marked with the text:

"This morning the sun has risen from sleep even though it's only five o'clock. I just wanted to start my morning routine, sitting pensive in the room of my house while watching television. Today's news covers a lot of women's emancipation. Ah ... yeah I just remembered today is Kartini Day. Emancipation.... suddenly this thought brought

\section{Short Story 5}

me to the memories of the past when I was still wearing a white-blue uniform. "

The subject in the short story "I" is the writer or narrator, marked by:

"When I wrote this letter, a wife in Bali was in pain because her legs were cut ..."

\subsection{Object Position \\ Short Story 1}

Short story "Me, Ratih and Kartini" the object of the story is Ratih and Kartini. Ratih is described as a woman who became a student and Kartini is a woman who fights for women's rights or is often called women's emancipation. following is the description of the object in the story:

"This is more painful. Hearing the fact is painful, even though he, who feels it. At the age of responsibility, a fifteen-year-old girl must be willing to lose her father first and then she can go to school. What ideology is that? Garbage ideology. How expensive we have to pay, if we go to school we have to lose the person we love so much. "

"dear Allah. Strengthen him. Education needs people like Ruth. A gaids who practice their principles well. Like Kartini. But, not ordinary Kartini. This one is extraordinary. Amen.

Furthermore, the second object in the short story is "Kartini":

"R.A Kartini was noted as someone who actively promotes gender justice and women's emancipation. born as a Jepara nobleman, Kartini grew up in a very thick environment that understood and practiced Javanese customs. Year to year his life is the most important moment in the process of understanding and interpreting his identity later. "

\section{Short Story 2}

The position of the object in the short story " Perempuan Berbaju Zirah " is used as told by the subject. So that in essence objects rarely display their own ideas, but their presence and ideas are displayed by other groups / people. This short story has an object position as the main character cannot present his will or ideas freely because there is another party who discriminates his wishes. As quoted below: 
"After that event you still pay attention to me being diligent in my next actions. Still firmly docked in line. Still shouting while clenching his fists. And still loudly singing

\section{Short Story 3}

Mars in the injustice of the rulers; we will win!....."

The position of objects in women's short stories and metalitas is factory women. Factory women have authority and cannot be denied and are separated that the character is as told (object). Marked in text:

"Women take a big role in the economy. Without a factory woman, only a building

that will be occupied by the bat

\section{Short Story 4}

In the story the object of the subject of the story is "me" even though he tells about himself.

"The tone of the message from my cellphone interrupted my thoughts. I have to hurry to get ready for the office. This morning's meeting starts early. After traveling thirty minutes from my house, this is where I am now. A multinational company that has five company leaders where of the five leaders, three of whom are women and I am one of the three. I am very happy to be able to realize my dream of being a leader. However, I realized that my success at this time was impossible to achieve without God's help and parental support. Besides that, I am very proud, because even though now I am not living in Indonesia, I can maintain a sense of nationalism that is always taught by my teacher and my family. I am very proud and grateful to be an Indonesian woman. "

\section{Short Story 5}

The position of the object in the story "Martini" is my son named (R).

"R, as I mentioned at the beginning of the letter, I wrote this letter while awaiting your birth, at my age of 29 years. In a state of pregnancy without being clear who the father of the fetus he was carrying" ...

Validation by material experts is intended to find out the opinions of material experts about the feasibility of presentation and language of the reading material product "Collection of Women's Emancipation Short Story". This validation was carried out by Dr. Abdurahman Adisaputera, M. Hum and Mara Untung Ritonga, S.S., M. Hum., Ph.D. who is a language lecturer at Medan State University. This validation is carried out to obtain the feasibility of quality products to improve Indonesian language learning at the MAN / SMA level, especially in short story material.

The results of the questionnaire showed that the feasibility aspects of the contents of the reading material products were stated to be $86.71 \%$. Content is declared feasible because it is at an average value above $75 \%$. Data on the eligibility of the contents can be seen in table 1 below.

Table 1. Material Validation

\begin{tabular}{|l|l|c|c|}
\hline \multicolumn{1}{|c|}{ Sub Component } & \multicolumn{1}{|c|}{ Assessment Indicator } & $\begin{array}{c}\text { Average } \\
\text { Percentage }\end{array}$ & Criteria \\
\hline $\begin{array}{l}\text { A. Compatibility of } \\
\text { material with } \\
\text { KI and KD }\end{array}$ & 1.Completeness of material & 87.5 & Very good \\
\cline { 2 - 4 } & 2. Material breadth & 87.5 & Very good \\
\hline B. Material & 1.The accuracy of the concept & 75 & Good \\
\hline
\end{tabular}




\begin{tabular}{|l|l|c|c|}
\hline \multirow{5}{*}{ accuracy } & \multicolumn{1}{|c|}{ and definition of short stories } & & \\
\cline { 2 - 4 } & 2. Accuracy of facts and data & 75 & Good \\
\cline { 2 - 4 } & 3. Accuracy of facts and data & 75 & Good \\
\cline { 2 - 4 } & 4. Accuracy of facts and data & 75 & Good \\
\cline { 2 - 4 } & 5. Accuracy of terms & 87.5 & Very good \\
\cline { 2 - 4 } & $\begin{array}{l}\text { 6.Accuracy of notations, } \\
\text { symbols and icons }\end{array}$ & 87.5 & Very good \\
\cline { 2 - 4 } & 7. Accuracy of references & 100 & Very good \\
\hline \multirow{2}{*}{$\begin{array}{c}\text { D. Encourage } \\
\text { curiosity }\end{array}$} & 1. Encourage curiosity & 87.5 & Very good \\
\hline Total Average & 2. Creating ability bertanya & 87.5 & Very good \\
\hline
\end{tabular}

Table 2. Percentage criteria for the appearance of indicators in reading material products "Kumpulan Cerpen Emansipasi Wanita" (Collection of Women's Emancipation Short Stories):

\begin{tabular}{|l|l|l|}
\hline \multicolumn{1}{|c|}{ No } & \multicolumn{1}{c|}{ Answer } & \multicolumn{1}{c|}{ Score } \\
\hline A & Excellent & $81 \% \leq \mathrm{X} \leq 100 \%$ \\
\hline B & Good & $61 \% \leq \mathrm{X} \leq 80 \%$ \\
\hline C & Medium & $41 \% \leq \mathrm{X} \leq 60 \%$ \\
\hline D & Fair & $21 \% \leq \mathrm{X} \leq 40 \%$ \\
\hline E & Unsatisfied & $0 \% \leq \mathrm{X} \leq 20 \%$ \\
\hline
\end{tabular}

(Sugiyono, 2011:118)

\begin{tabular}{|c|l|c|c|}
\hline $\begin{array}{c}\text { Sub } \\
\text { Component }\end{array}$ & \multicolumn{1}{|c|}{ Assessment Indicator } & $\begin{array}{c}\text { Average } \\
\text { Percentage }\end{array}$ & Criteria \\
\hline $\begin{array}{c}\text { A. Presentation } \\
\text { Techniques }\end{array}$ & $\begin{array}{c}\text { 1.Systematic consistency of } \\
\text { presentation in learning activities }\end{array}$ & 75 & Good \\
\cline { 2 - 4 } & 2.Creed concept & 75 & Good \\
\hline $\begin{array}{c}\text { B.Presentation } \\
\text { of Learning }\end{array}$ & 1.Involvement of students & 87,5 & Very good \\
\cline { 2 - 4 } & 2.Student-centered & 87,5 & Very good \\
\cline { 2 - 4 } & $\begin{array}{c}\text { 3.Stimulating students' ability to solve } \\
\text { problems through illustrations }\end{array}$ & 100 & Very good \\
\hline $\begin{array}{c}\text { C.Presentation } \\
\text { Completeness }\end{array}$ & 1. Preface & 100 & Very good \\
\cline { 2 - 4 } & 2. Table of Contents & 100 & Very good \\
\cline { 2 - 4 } & 3. References & 100 & Very good \\
\cline { 2 - 4 } & 4. Writer biography & $\mathbf{9 1 . 6 6}$ & Very good \\
\hline Total Average & & &
\end{tabular}

Table 3. The Percentage Criteria for the Appearance of Indicators on the Reading Material Product "Kumpulan Cerpen Emansipasi Wanita" (Collection of Women's Emancipation Short Stories) That Has Been Developed.

\begin{tabular}{|c|l|c|}
\hline No. & \multicolumn{1}{|c|}{ Answer } & Score \\
\hline A & Excellent & $81 \% \leq X \leq 100 \%$ \\
\hline B & Good & $61 \% \leq X \leq 80 \%$ \\
\hline
\end{tabular}




\begin{tabular}{|c|l|l|}
\hline C & Medium & $41 \% \leq \mathrm{X} \leq 60 \%$ \\
\hline D & Fair & $21 \% \leq \mathrm{X} \leq 40 \%$ \\
\hline E & Unsatisfied & $0 \% \leq \mathrm{X} \leq 20 \%$ \\
\hline
\end{tabular}

(Sugiyono, 2011:118)

The results of the questionnaire showed that the feasibility aspect discussed the reading material "Kumpulan Cerpen Emansipasi Wanita" (Collection of Women's Emancipation Short Stories) with an average percentage of $82.8 \%$. This means that the presentation of material in reading material products is deemed feasible because it is above $75 \%$. Assessment of the language in the material is declared not feasible if it obtains an average value below $75 \%$. Data on the feasibility of the presentation language can be seen in the following table.

The research process on reading material products "Kumpulan Cerpen Emansipasi Wanita" (Collection of Women's Emancipation Short Stories) through several stages, namely the test of needs analysis and the feasibility test of reading material carried out by a team of experts on material validation and design. The needs analysis phase distributes questionnaires to 26 students and conducts interviews with 2 Indonesian language study teachers. The needs analysis was carried out to determine the priorities of the needs of students and teachers, gather information and solve problems related to the use of reading material found in MAN Insan Cendikia, East Aceh.

Based on the needs analysis, information was obtained that all this time teachers and students only used books given to the Ministry of Education and Culture in the learning process. The teacher does not provide additional books for students. The teacher also provides information that there is no literary material in the current school library. The teacher hopes that the reading material can support the learning process.

The results of the needs analysis questionnaire to students and interviews with teachers stated that all teachers $(100 \%)$ stated that there were no literary material in the school. All teachers $(100 \%)$ in the Indonesian language study field do not have a book of short stories. All teachers $(100 \%)$ stated that there was no reading material in the form of literature in the library of the East Aceh Scholar Man. All teachers (100\%) need reading material in the form of short stories to support the learning process so students are more interested in learning. Nearly $(100 \%)$ students answered that in MAN Insan Cendikia, East Aceh does not yet have literary material.

The results of the needs analysis also indicate that teachers and students really need reading material and are interested in reading material "a collection of women's emancipation short stories". The help of this reading material in the learning process can help students more easily learn short stories, so that it adds insight into both vocabulary and the addition of student reading material.

Validation of reading material is done by material experts and design experts. Material validation was carried out by Dr. Abdurahman Adisaputera, M. Hum and Mr Mara Untung Ritonga, S.S., M. Hum., Ph.D. while the design expert was conducted by Ms. Surya Masniari Hutagalung, M.Pd. and Dr. Evi Eviyanti, M.Pd. The results of the validation by experts on each aspect of the assessment are determined by the average score of the respective criteria. The results of the assessment determine whether or not the reading material is "a collection of short stories of female emancipation". the average percentage of the results of the assessment by material experts and design is assessed based on aspects and indicators of assessment. 
Assessment carried out by material experts on reading material consisted of 3 aspects, namely aspects of content feasibility, feasibility of presentation and language feasibility. The results of the assessment on the aspect of content eligibility were stated as "Excellent" with an average presentation of $86.7 \%$. The assessment on the presentation aspect was stated as "Excellent" with a total of 91.6\%. Language feasibility assessment $82.8 \%$ with the category "Excellent". There are several suggestions from the validator listed in table 4 below.

Table 4. Suggestions from the Material Validator

\begin{tabular}{|l|l|}
\hline No & Suggestion \\
\hline 1 & Make the short story concept clearly \\
\hline 2 & $\begin{array}{l}\text { Make how reciprocal reading material you make for teaching materials in } \\
\text { school }\end{array}$ \\
\hline 3 & There must be a function for learning at school \\
\hline
\end{tabular}

The assessment carried out by product design experts in reading material is intended to improve the quality of display of reading material. The results of the validation by design experts were stated as "Excellent" with an average presentation of $82.08 \%$. Suggestions from design expert validators both in writing and in general are helpful in the following table.

Table 5. Advice from Design Validators

\begin{tabular}{|l|l|}
\hline No & Suggestion \\
\hline 1 & $\begin{array}{l}\text { We recommend that the image source is listed below the image and add answers } \\
\text { to the student's understanding exercise. }\end{array}$ \\
\hline 2 & $\begin{array}{l}\text { Revised cover color combinations, outer back cover because the color } \\
\text { combination is less harmonious. }\end{array}$ \\
\hline 3 & The design of each short story title must be consistent, don't be different! \\
\hline 4 & Revise short font letters to be comfortable to read \\
\hline 5 & Revise short font letters to be comfortable to read \\
\hline
\end{tabular}

The results of the assessment of reading material on the material indicator obtained an average percentage value of $86.7 \%$ with the category "Excellent", an indicator of accuracy of an average percentage of $82.1 \%$ with the category "Excellen". The material update indicator obtained an average percentage value of $92.5 \%$ with the category "Excellent". Indicators encourage curiosity to obtain an average value of $87.5 \%$ with the category "Excellent". Furthermore, the presentation technique indicators obtain an average value of $75 \%$ with the category "Good". The indicators for presenting learning obtain an average score of $91.6 \%$ with the category "Excellen". The last indicator is the completeness of the presentation obtained an average of $100 \%$ with the category "Excellent". If all indicators are summed with an average value of $86.7 \%$ with the category "Excellent". This means that the reading material "collection of women's emancipation short stories" has met the needs of learning and is suitable for use in the teaching and learning process.

The results of language assessments in the book "Kumpulan Cerpen Emansipasi Wanita" (Collection of Women's Emancipation Short Stories) obtained an average percentage value of $82.8 \%$ in the good category. The straightforward indicator obtained $79.2 \%$ with the category "Good". The communicative indicator obtained an average value of $81.3 \%$ with the category "Excellent". Dialogic and interactive indicators obtain an average score of $87.6 \%$ in the "Excellent"category. Indicator D. Suitability with the level of development of students obtains an average value of $81.3 \%$ with the category "Excellent". 
Indicators of clutter and integration of the mindset obtain an average value of $93.8 \%$ with the category "Excellent". The use of terms, symbols and icons obtain an average value of $75 \%$ with the category "Good".

The results of the assessment of reading material on the design indicator obtained an average value of $82.08 \%$ with the category "Excellent". The indicator of graphic feasibility obtained an average value of $87.5 \%$ with the category of "Excellent", the indicator of the design of reading material obtained an average score of $76.3 \%$ with the category "Good". The indicators for the design of the contents of the reading material received an average value of 84.2\% with the category "Excellent". It can be concluded that the reading material "Kumpulan Cerpen Emansipasi Wanita" (Collection of Women's Emancipation Short Stories) is worthy of being used as reading material for $10^{\text {th }}$ Grade Students of MAN Insan Cendikia, East Aceh. The final stage of the reading material process "Kumpulan Cerpen Emansipasi Wanita" (Collection of Women's Emancipation Short Stories) is to hold students' responses to reading material products. Literary teaching basically has a role in increasing students' understanding. If literary works do not have the benefit of interpreting real-world problems, then literary works are not of value to the reader. The literary works in this reading material are in the form of short stories using the theme "Emancipation of Women".

Literary learning that is relevant for students' character development is learning that allows students to grow awareness to read and write literary works that ultimately can improve understanding and understanding of humans and humanity, recognize values, get new ideas, increase socio-cultural knowledge , developing feeling and intention, and building character and personality. Literary appreciation will grow in line with expectations when Indonesian language and literature teachers also love literature. The novel allows a student with the ability to read it, swept away in preoccupation (Rahmanto, 1988-65).

Based on the student questionnaire responses by looking at the results of the statements by obtaining a percentage of $84.7 \%$, explaining that the reading material "collection of women's emancipation short stories" is feasible to be implemented as student reading material and teaching materials to be used as references by teachers when teaching and learning.

Reading material that has been tested is through several experiments, namely validation test, teacher test and student understanding test can be used as a reference for students' reading. This reading material can also be one of the teaching and learning processes, thus helping the teacher in explaining the short story. The teacher can also use this reading material as an analogy for short stories for students. Obviously, the reading material "Kumpulan Cerpen Emansipasi Wanita" (Collection of Women's Emancipation Short Stories) also adds to the reading of students in 10th Grade Students of MAN Insan Cendikia, East Aceh.

\section{Conclusion}

The process for reading material products "Kumpulan Cerpen Emansipasi Wanita" (Collection of Women's Emancipation Short Stories) has three stages, namely needs analysis, material and design expert validation and the last is student responses questionnaire about reading material products. Need analysis All teachers (100\%) in the Indonesian language study field do not have a book of short stories. All teachers (100\%) stated that there was no reading material in the form of literature in the library of MAN Insan Cendikia, East Aceh. 
All teachers $(100 \%)$ need reading material in the form of short stories to support the learning process so students are more interested in learning. Nearly (100\%) students answered that in the school of MAN Insan Cendikia, East Aceh does not yet have literary material. Reading material in MAN Insan Cendikia, East Aceh school is only in the form of reading about science not in the form of literature. The material expert validation stage obtained results from these assessments indicating that the feasibility aspects of the material content of reading material products were declared $86.71 \%$ with the category "Excellent". The contents are declared feasible because they are in the average value above $75 \%$ with the category "Good". Furthermore, the assessment of this design was carried out to improve the display quality of the reading material "Kumpulan Cerpen Emansipasi Wanita" (Collection of Women's Emancipation Short Stories). The results of the design expert's validation showed that the reading material was in the category of "Excellent" with an average percentage of $82.08 \%$. The final stage in the reading material product process is the student's response to the product is a questionnaire of 26 student responses, that the reading material "Kumpulan Cerpen Emansipasi Wanita" (Collection of Women's Emancipation Short Stories) is appropriate to be used for student reading and as a reference for teacher teaching materials. The average number of percentage values obtained from each component of the statement has a percentage of "Excellent", so that it can be implemented as a reading of students with a value of $84.7 \%$.

\section{References}

Afifuddin dan Beni Ahmad Saebani. 2009. Metodologi Penelitian Kualitatif. Bandung: Pustaka Setia

Agustama, Ridhani. Wacana Kekerasan Fisik dalam Komik JurnalistikFootnotes in Gaza. Jurnal komunikasi, ISSN 1907-898XVolume 8, Nomor 2, April 2014.

Aminuddin. 2010. Apresiasi Karya Sastra. Bandung: IKAPI.

Aryaningsih, dkk. 2013. Pengembangan Bahan Ajar Memmbaca Sastra Indonesia dan Perangkat Penilaian Autentik Siswa Kelas XII Semester 1 SMA 11 Denpasar. Jurnal Program Pascasarjana Universitas Pendidikan Ganesha, Denpasar. Universita Pendidikan Bahasa.

Budianta, Melani. (2002). Pendekatan Feminis Terhadap Wacana: Sebuah Pengantar. Dalam I. D. Aminuddin, Analisis Wacana: Dari Linguistik Sampai Dekonstruksi. Yogyakarta: Kanal.

Brown, Gillian dan George Yule. 1996. Analisis Wacana. Jakarta: PT Gramedia Pustaka Utama.

Damono, Sapardi Djoko. 1983. Kesusastraan Indonesia Modern; Beberapa Catatan. Jakarta: Gramedia.

Dalman. 2013. Keterampilan Membaca. Jakarta: Raja Grafindo Persada.

Darma, Yoce Aliah. 2009. Analisis Wacana Kritis. Bandung: Yrama Widya.

Denny Eko Prasetyo. 2016. Analisis Berita Yuyun dan Para Korban Kejahatan Akibat Minuman Keras di Republika Online Edisi 7 Mei 2016. E-Journal Ilmu Komunikasi, ISSN 2502-597X.

Depdiknas. 2012. Kamus Besar Bahasa Indonesia. Jakarta: P.T Gramedia Pustaka Umum.

Endraswara, Suwardi. 2011. Metodologi Penelitian Sosiologi Sastra. Yogyakarta:CAPS.

Eriyanto. 2001. Analisis Wacana: Pengantar Analisis Teks Media. Yogyakarta: LkiS 
Budapest International Research and Critics in Linguistics and Education (BirLE) Journal

Volume 2, No 3, August 2019, Page: 203-215

e-ISSN: 2655-1470 (Online), p-ISSN: 2655-2647 (Print)

www.bircu-journal.com/index.php/birle

emails: birle.journal@gmail.com

birle.journal.qa@gmail.com

2006. Analisis Wacana: Pengantar Analisis Teks Media Yogyakarta: LkiS Pelangi Aksara.

2009. Analisis Wacana: Pengantar Analisis Teks Media. Yogyakarta: PT LkiS Printing Cemerlang.

Fauziah. 2015. Representasi Perempuan dalam Pemberitaan KDRT di Media Massa Pada Masyarakat di Wilayah Jakarta (Studi Pemberitaan Kekerasan dalam Rumah Tangga di Merdeka.com dan Kompas.com). Jurnal Promedia, Volume 1, No 1, 2015, pp. 131158).

Hamdani. 2011. Strategi Belajar Mengajar. Bandung. Pustaka Setia.

Hendrastuti, Retno. 2013. Sastra Terjemahan Sebagai Bahan penunjang Pengajaran Sastra. Jurnal Jakarta: Balai Bahasa.

Istiqomah. 2016. The Development of Learning Materials. Journal of Education and Research. 4 (9): 313-322.

Kazim, Syed Shah,dkk. 2014. Representation of Women in Mann O Salwa: A Case Study through Feminist Stylistic Analysis. Research on Humanities and Social Sciences. ISSN (Paper)2224-5766 ISSN (Online) 2225-0484 Volume. 4, No. 7.

Kutha, Ratna Nyoman. 2008. Teori Media dan Teknik Penelitian Sastra. Yogyakarta:Pelajar.

Kosasih, E. 2011. Ketatabahasaan dan Kesusastraan. Bandung: CV.Vrama Widya.

Ma'ani, Achmad Syafi'I. 2013. Agama Politik Moral. Malang: Anggota IKPI.

Mills, Sara. (2002). Discourse: The New Critical Idiom. New York: Routledge.

Mulia, Siti Musdah. 2006. Islam dan Inspirasi Kesetaraan Gender. Yogyakarta:

Moleong, Lexy J. 2014. Metodologi Penelitian Kualitatif. Bandung: P.T. Remaja Rosdakarya. Kibar Press.

Ningsih, Wahyu. 2018. Nilai-Nilai Edukasi Islam Dalam Novel "Pudarnya Pesona Cleopatra" (Analisis Wacana Kritis Model Sara Mills). Jurnal Bahasa, Sastra, dan Pengajarannya. P-ISSN-5778 Volume 6 No. 2 Agustus pp. 47-56.

Nike, Kusumawati. 2016. Pengembangan Bahan Ajar Teks Eksplanasi Mata Pelajaran Bahasa Indonesia SMP dengan Media Web Offline. Tesis: Program Pascasarjana Universitas Negeri Malang.

Nurgiyantoro, Burhan. 1994. Teori Pengkajian Fiksi. Yogyakarta: Gadjah Mada University Press.

2005. Sastra Anak (Pengantar Pemahaman Dunia Anak). Yogyakarta: Gajah Mada Universitas Press.

-------2002. Teori Pengkajian Fiksi. Yogyakarta: Gadjah Mada University Prees.

Nursisto. 2000. Ikhtisar Kesustraan Indonesia. Yogyakarta: Adicitra Karya Nusa.

Orwella, Citra. 2017. Representasi Gerakan Politik Perempuan dalam News Journalism (Analisis Teks Berita Koran Lama Tentang Gerwani PKI dan Pemilu 2014). Jurnal Media Komunikasi Sosial Keagamaan, Vol. 17, No.1, July.

Prastowo, Andi. 2015.Panduan Kreatif Membuat Bahan Ajar Inovatif. Yogyakarta: Diva Press.

Priyatni. E. 2010. Membaca dan Menulis Di SD. Bandung: UPI Press.

Rampan, Korie Layun. 2009. Apresiasi Cerpen Indonesia Mutakhir. Jakarta: Bukupop.

Ratna, Nyoman Kutha. 2008. Teori, Metode, dan Teknik Penelitian Sastra. Yogyakarta: Pustaka Pelajar

Riduwan. 2004. Metode Penelitian untuk Tesis. Bandung Alfabeta. 
Rimmon-Kennan, Schlomith. (2002). Narrative Fiction: Contemporary Poetics $2^{\text {nd }}$ Edition (New Accents). London: Routledge. E-book. Source: http://en.bookfi.org/book/1039917 (downloaded on February 21, 2019, at 01.44 WIB).

Rohmah, Rina Ari. Juni 2017.Potret Wanita Berita Kriminal Pemerkosaan Di Media Online Sindonews.Com. Jurnal Pendidikan Rokania Vol. II (No. 2/2017) 247 - 264 ISSN. 2527-6018 e-ISSN. 2548-414.

Romli, Rosnandar, dkk. 2018. Representasi Perempuan dalam Film Ayat-Ayat Cinta. Jurnal Komunikasi Global, Volume 7, Nomor 2.

Sanjaya, Wina. 2014. Penelitian Pendidikan: Jenis, Metode dan Prosedur. Jakarta: Kencana.

Sharma, Arvind. 2002. Perempuan Dalam Agama-Agama Dunia. Perguruan Tinggi Agama Islam Depertemen Agama RI.

Semi, Atar. 1989. Kritik Sastra. Bandung: Angkasa.

Sugiyono. 2012. Metode Penelitian Pendidikan: Pendekatan Kuantitatif, Kualitatif, dan $R$ \& $D$. Bandung:Alfabeta.

Sukaesih, Ina dan Lenny Brida. 2017. Assessing Text Aligment: Sara Mills'Model.Eipgram Vol. 14 No.1 April.

Suwandi, Sarwiji Mastini dan Sumarwati.2016. Peningkatan Keterampilan Menulis Cerpen Melalui Metode Pembelajaran Berbasis Pengalaman Dan Media Audiovisual Pada Sekolah Menengah Pertama.Volume 1, No. 1, August 2016 http://jurnal.fkip.uns.ac.id/index.php/s2indo.

Syaodih, Nana. 2015. Pengembangan Bahan Ajar. Jakarta: Perdana Mulya Sarana.

Tarigan, Henry Guntur. 2008. Menulis Sebagai Suatu Keterampilan Berbahasa. Bandung: Angkasa.

Yanti, Citra Salda.2015. Religiositas Islam Dalam Novel Ratu Yang Bersujud Karya Amrizal Mochamad Mahdavi.Jurnal Humanika No. 15, Vol. 3, December 2015 / ISSN 19798296.

Wardana,dkk. 2016. Analisis Unsur Intrinsik dalam Antologi Cerpen Aku Sayang Saudaraku Karya Albye Syafie Sebagai Bahan Pembelajaran Menulis Karangan Narasi Bagi Siswa Kelas V Di Sekolah Dasar. Kalimaya: Volume 4, Nomor 2, Agusutus.

Wahid, Sugira. 2004. Kapita Selekta Kritik Sastra. Makassar: Universitas Negeri Makassar.

Wahyuddin, Wisrawaty. 2016. Kemampuan Menentukan Isi Cerita Rakyat Siswa Kelas X SMA Negeri 1 Raha. Jurnal Bastra, Vol.1, No. 1, March. 